\title{
WEAR CALCULATION FOR SLIDING FRICTION PAIRS
}

\author{
G. Springis, J. Rudzitis, A. Avisane, A. Leitans \\ Riga Technical University, \\ 6 Ezermalas Str., Riga, LV-1006, LATVIA \\ e-mail: guntis.springis@rtu.lv
}

\begin{abstract}
One of the principal objectives of modern production process is the improvement of quality level; this means also guaranteeing the required service life of different products and increase in their wear resistance. To perform this task, prediction of service life of fitted components is of crucial value, since with the development of production technologies and measuring devices it is possible to determine with ever increasing precision the data to be used also in analytical calculations. Having studied the prediction theories of wear process that have been developed in the course of time and can be classified into definite groups one can state that each of them has shortcomings that might strongly impair the results thus making unnecessary theoretical calculations. The proposed model for wear calculation is based on the application of theories from several branches of science to the description of 3D surface micro-topography, assessing the material's physical and mechanical characteristics, substantiating the regularities in creation of the material particles separated during the wear process and taking into consideration definite service conditions of fittings.
\end{abstract}

Keywords: wear, calculation model, 3D surface, roughness.

\section{INTRODUCTION}

The wear process is characterised and affected by different parameters: the geometry of surface peaks (roughness, buckles, shape deviations, etc.), physicallymechanical conditions of the upper layer, material of components, temperature of sliding fittings during the wear process, wear conditions, etc.

Already initially it was implied that all these factors are impossible to take into consideration in the analytical calculation; therefore, the wear calculation development in the course of time went in different directions. Each of them resulted in theoretical estimation of affecting quantities. Historically, several models of the wear process have been developed which allow approximate prediction of the friction pairs' service life.

\section{SHORT SURVEY OF WEAR CALCULATION THEORIES}

The first calculation model is closely connected with application of the probability theory to prediction of the fittings' service life. Thus, at the failure 
intensity assumed constant ( $\lambda=$ const $)$ the probability of no-failure operation can be calculated by the following formula:

$$
P(t)=e^{-\lambda t} .
$$

Therefore, it is possible to predict unexpected failures of a friction pair's operation. An advantage of this model is the comparative simplicity. At the same time, its shortcoming is that parameter $\lambda$ must be found preliminarily; besides, this model does not take into account the factors affecting directly the operation of a component (its physical and mechanical properties such as movement speed, load, etc.)

The second model is firmly based on the laws of classical physics. The supporter of this model R. Holms associates the wear process with interaction of atoms on the contacting surfaces followed by their separation, proposing to calculate the volume of a worn-out material by the formula:

$$
W=z \frac{N}{H B},
$$

where $N \quad$ is the applied load;

$H B \quad$ is the Brinell hardness of the material;

$z \quad$ is the probability of separation from the surface of an atom in the case it comes into contact with an atom of another body.

In turn, C.D. Strong considers that during the wear process the material particles separate according to the dislocation theory principles; yet another scientist E. Rabinovich connects the surface particle separation process with surface energy phenomena. However, this approach makes impossible regulation of wear processes on the level of engineers' task.

The third calculation model links the wear speed $\gamma$ with specific pressures $p$ of friction pairs and relative sliding movement speed $v$. A. Pronykov identifies two wear types - the surface wear and the friction fitting's wear.

Surface wear is characterised by the change of a component's size in the direction perpendicular to the friction surface $\Delta h$. In the general case, wear is spreading on the friction surface irregularly, therefore:

$$
\Delta h=f(x, y),
$$

where $x$ and $y$ are the friction surface coordinates.

In the case of friction of two fitted surfaces both of them are wearing simultaneously. This leads to the changes in the mutual position of these surfaces. The friction pair's wear is determined by analysing the changes in the geometrical position of fitted components that occur at their interaction. For example, the abrasive wear of a cone-shaped fitting according to the above approach is calculated as

$$
\gamma_{1-2}=\frac{\operatorname{Pn}\left(K_{1}+K_{2}\right)}{(R-r) \cos \alpha},
$$

where $P \quad$ are the load affecting components;

$n \quad$ is the number of turns; 


$$
\begin{array}{ll}
K_{1}, K_{2} & \text { are the wear resistance coefficients of components; } \\
R, r & \text { are the maximum and minimum radii } \\
\text { of the friction surface contact. }
\end{array}
$$

It is crucial that these calculations are based on the material wear regularities and estimate a fitting's configuration; however, coefficients $K_{1}, K_{2}$ in the formula could be found only in long-lasting experiments, so there is no sense to make preliminary wear calculations.

The fourth calculation model includes the friction pair's structural characteristic quantities and physical \& mechanical parameters of the material of friction components as well as geometrical parameters of the components' surfaces. This model takes into consideration not only the impact of material hardness and load on the friction pair, but also characteristic quantities of a definite material's flexibility, mode of component operation (load, speed, temperature), external conditions (lubrication, environment), and the constructive peculiarities of the friction pair. In particular, the worn-out material volume can be described as

$$
V_{e}=\frac{k b \varepsilon^{v+1} A_{c} R_{\max }}{(v+1) \alpha n},
$$

where $k \quad$ is the coefficient accounting for the actual deformed volume;

$b, \quad v$ are the approximation coefficients of a surface's relative support area;

$\varepsilon \quad$ is the relative convergence of two surfaces;

$\alpha \quad$ is a coefficient characterising the stress and kinematic situation on the contact area;

$R_{\max } \quad$ is the maximum height of profile roughness;

$A_{c} \quad$ is the contact area surface;

$n \quad$ is the number of effects causing the material's destruction.

The shortcoming of this calculation model is that at characterisation of the friction component's surface parameters the non-standard roughness parameters $b$ and $v$ are used, which implies additional calculations. Of importance is also the fact that all these parameters are only profile parameters, while the real friction pair surface is a spatial object.

The fifth calculation model as compared with the fourth one, in addition to the above wear calculation parameters takes into consideration the 3D surface roughness values according to ISO 25178-2:2012 standard at modelling the surface's micro-topography with the random field theory while the friction surfaces' destruction - with the fatigue theory. The most characteristic quantities of this model and the relevant methods for wear process calculation are considered below.

\section{SURFACE ROUGHNESS MODELLING BASED ON THE NORMAL RANDOM FIELD THEORY}

The description of the friction surface's micro-topography, particularly in the case of irregular surface roughness, is rather a complicated process owing to the different height of surface roughness peaks and their various configurations. In practice, the roughness description models have been developed based on correct 
geometrical shapes: for example, of bar shape, spherical, cone-type (also truncated cone), elliptic, cylindrical, prism shape, etc. At the same time, the real irregular surface roughness profiles strongly deviate from the ideal. Therefore, scientists are striving to apply as complete as possible rough surface profile descriptions.

For studying the irregular surface roughness (which is very important in practice) efficient is the random function theory, thus the surface micro-topography can be described by a $2 \mathrm{D}$ random function, i.e. random field $h(x, y)$ with two variables $(x$ and $y)$ [1].

For characterising the random function of importance is the correlation function, which shows correlation between the random function points, thus the faster the correlation function diminishes the more chaotic is the random function. The correlation function depends on two variables: $\tau_{1}$ and $\tau_{2}$, which are the projections of vector $\tau$ connecting two surface points on the abscissa and ordinate axes in Cartesian's coordinate system [1]. The irregular surface roughness is exemplified in Fig.1.

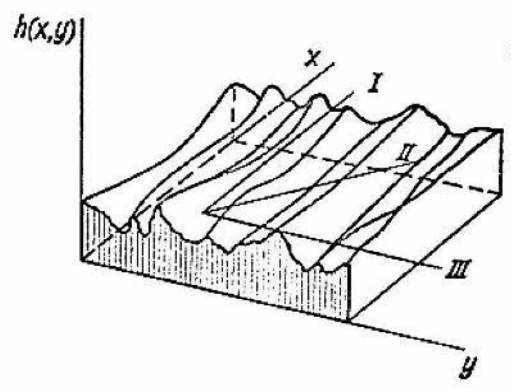

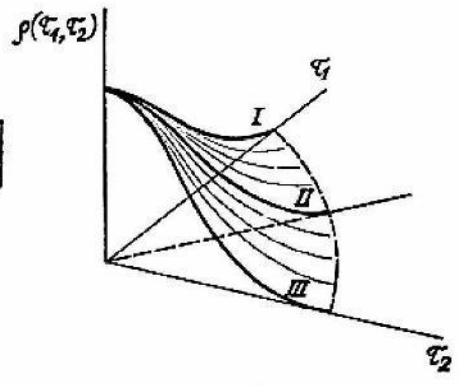

Fig.1. Schematic depiction of irregular surface roughness (a) and corresponding standardised correlation function (b).

In view of the above, to the proposed calculation model the following definition can be applied: the surface roughness is described by a normal uniform two-variable random field $h(x, y)$ which possesses ergodic properties and whose correlation function is uninterrupted and has uninterrupted derivatives. Without losing the essence we can assume that the mathematical expectation (ME) is $E\{h(x$, $y)\}=0$. The mean value of random field is constituted by the plane which can be called a mid-plane. Thus, to describe a normal random field the mathematical expectation of this field and correlation function should be known.

\section{Initial parameters}

We will consider a cluster of initial parameters for the given model. We can assume that the area has been set when its dispersion and standardised correlation function are known, the requirement to find the area dispersion leads to finding $S_{a}$ (the standard arithmetic deviation from the mid-plane) for the surface, and the requirement to solve the problem $\rho\left(\tau_{1}, \tau_{2}\right)$ - to determination of the corresponding roughness step parameter $R S_{m l}$ (a step perpendicular to the processing trace direction along midline) and $R S_{m 2}$ (a step towards the processing trace along the midline) shown in Fig.2. 


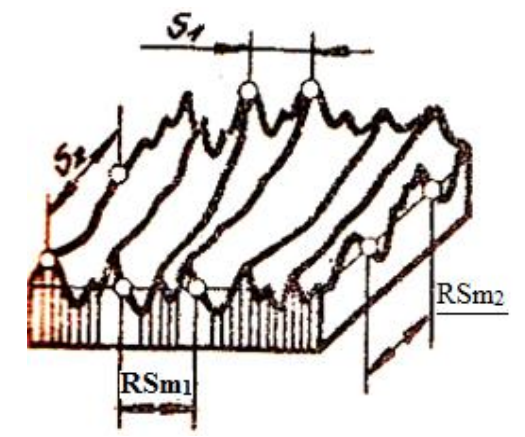

Fig.2. 3D parameters of irregular surface roughness.

Step parameters $R S_{m 1}$ and $R S_{m 2}$ allow determination of the anisotropy coefficient $c[2]$ :

$$
c=\frac{E\left\{n_{2}(0)\right\}}{E\left\{n_{1}(0)\right\}},
$$

where $n_{1}(0), n_{2}(0)$ are the numbers of zeros in two mutually perpendicular directions of surface cuts $x$ and $y$ (i.e. in the longitudinal and transversal roughness directions of the surface).

The number of zeroes is that of crossings with midline, i.e. points which can be determined easily on the profilogram of Fig.3.

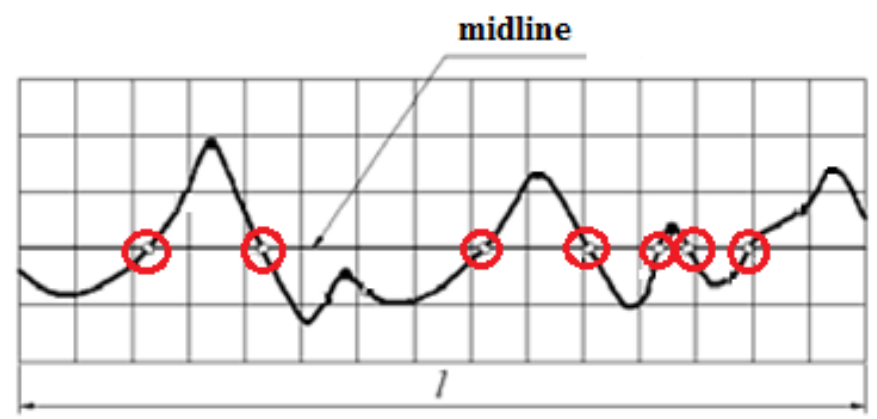

Fig.3. Points on profilogram midline characterising the numbers of zeroes.

Thus it can be assumed that

$$
c=\frac{E\left\{S_{m 1}\right\}}{E\left\{S_{m 2}\right\}} .
$$

The anisotropy coefficient $c$ varies from 0 to 1 . At $c=1$ the area is isotropic, while at $c=0$ it is maximum stretched (i.e. in one direction assuming a straight line).

Therefore, having a cluster of initial parameters for a rough surface we can propose the following definition: according to the height, a rough surface can be described using $S_{a}$, whereas in the longitudinal direction - using roughness steps in longitudinal direction $S_{m 1}$ and transversal direction $S_{m 2}$.

The number of contacting surfaces' peaks should be mentioned as one of the most important parameters of wear processes. For the use of the initial parameters 
it is crucial to know the mathematical expectation $E\{N \gamma\}$ of the number of rough surface peaks [2]:

$$
E\{N \gamma\} » \frac{\pi c E^{2}\left\{n_{1}(0)\right\}}{2 \sqrt{2 \pi}} \gamma e^{-\frac{\gamma^{2}}{2}},
$$

where $\gamma \quad$ is a relative cut height standardised by $\sigma$;

$e \quad$ is an exponential function.

The relative cut height $\gamma$ can be calculated as

$$
\gamma=\frac{u}{\sigma}
$$

where $u \quad$ is the cut height determined from the average area value;

$\sigma \quad$ is the mean square deviation of surface roughness.

At a relatively high cut $(\gamma>1)$ formula (8) can be simplified. Assuming that $\gamma=2$ we can write:

$$
E\left\{N_{\gamma}\right\} \approx \frac{1}{6} E\left\{n_{1}(0)\right\} E\left\{n_{2}(0)\right\} .
$$

Next, we must know also the ME of the average height of surface roughnesses $E\left\{\xi_{a}\right.$ $(\gamma)\}$, which at $\gamma>1$ can be determined as [3]

$$
E\left\{\xi_{a}(\gamma)\right\}=\gamma+\frac{1}{\gamma} .
$$

It is also necessary to know the peak curvature. Asymptotic dependence of the main peak curvatures above the $\gamma$ level can be calculated in the following way [2]:

$$
\begin{aligned}
& E\left\{k_{1}\right\}=\frac{2 \pi^{2} \sigma \gamma}{E^{2}\left\{S_{m 1}\right\}}, \\
& E\left\{k_{2}\right\}=\frac{2 \pi^{2} \sigma \gamma}{E^{2}\left\{S_{m 2}\right\}},
\end{aligned}
$$

where $k_{1}$ and $k_{2}$ are the main peak curvatures in mutually perpendicular directions.

With the help of given initial parameters we can calculate different $3 \mathrm{D}$ surface roughness parameters [2].

\section{PRINCIPLES OF THE FRICTION SURFACE FATIGUE THEORY}

In previous research works (see references in [3]) the fatigue character of the wear process has been proved. This means that the wear of contacting materials results in the formation and spreading of cracks, which finally leads to separation of the material particles.

Under cyclic loads some stresses can exceed the limit over which the material's upper layer suffers damages, with appearance and broadening of cracks. It should be mentioned that at the mutual movement of peaks every peak of a definite height deforms another peak, thus creating a stress area [3]. Since the 
peaks of contacting surfaces have different heights, the stress on the upper peak is a variable value (see Fig.4).

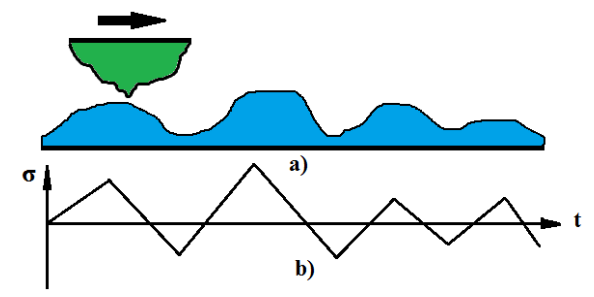

Fig.4. Schematic of irregular rough surfaces:

a) the effect of mutual peak loading; b) stress variations.

Using the linear summation of stress [3] and assuming that its amplitude distribution complies with that of the roughness peaks, the average number of cycles for material destruction can be determined by the following formula [3]:

$$
E\left\{N_{c}\right\}=\frac{N_{0}}{5 m !} t_{\sigma}^{m}
$$

where $t_{\sigma} \quad$ is the non-dimensional stress relation;

$N_{0} \quad$ is the number of material durability cycles at a symmetrical load;

$m \quad$ is the degree of the fatigue curve equation.

In turn, $t_{\sigma} \quad$ is calculated using the following coherence [3]:

$$
t_{\sigma}=\frac{\sigma_{-1}}{E\left\{\sigma_{a}\right\}},
$$

where $\sigma_{-l}$ is the material durability limit.

Parameters $\left(N_{0}, m, \sigma_{-1}\right)$ in formulas (14) and (15) have the mean values for definite material type.

From formula (15) it follows that the number of material destruction cycles is connected with stress amplitude $\sigma_{a}$, which can be determined from the foermula:

$$
E\left\{\sigma_{a}\right\} \approx \frac{\pi \sqrt{\pi} \sigma E\left\{n_{1}(0)\right\} E}{K(e)},
$$

where $\sigma \quad$ is the standard deviation;

$E\left\{n_{l}(0)\right\}$ is the ME of the number of zeroes (towards the $x$-direction of surface cuts);

$E \quad$ is the material's elasticity modulus;

$K(e) \quad$ is the first-order elliptical integral from the contact surface eccentricity.

Formula (15) is obtained on condition that the friction process has stabilised and the friction surface roughness is stretched towards the friction direction; thus the anisotropy coefficient $c \approx 0$ and $e \approx 1$.

Therefore, the number of cycles for material destruction can be determined knowing the fatigue destruction parameters $\left(N_{0}, m, \sigma_{-l}\right)$ of material, standard deviation $(\sigma)$, surface roughness parameters $\left(R S_{m l}, R S_{m 2}, c\right)$, and the material elasticity modulus $(E)$. 


\section{FORMATION OF PARTICLES IN A SURFACE WEARING PROCESS}

To understand better the formation of stress area between two elastically contacting bodies we should consider the peak deformation mechanics (see Fig.5). For the sake of clearness this figure shows the main stress areas for the upper peak only. It could be seen that for the upper peak the stress area shifts from right to left, and the stress intensity is changing in dependence on the mutual disposition of bodies. At the beginning of contact the peak is pressed to one side, but at the end to the other. In the contact, both compression and tension stresses arise, and their intensity increases with the friction coefficient.

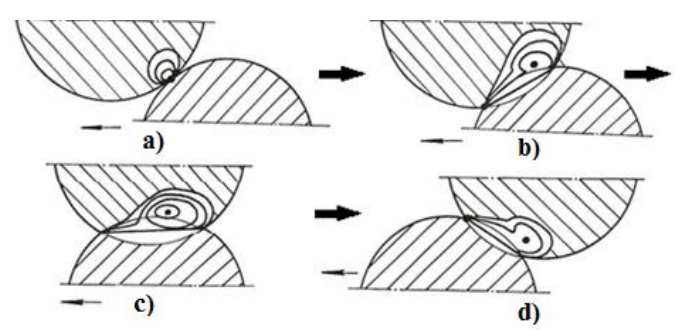

Fig. 5. Diagram of stress zone movements in the case of elastic contact between two peaks: a, b, c, d - stress in the peak contact area (Hertz' contact $[3,4]$ ).

The stress area diagram in Fig.5 shows - in compliance with Hamilton's theory [3, $4]$ - the changes in the contacting surface stress in dependence on the friction coefficient. In Fig.6 it is seen that at the friction coefficient $f=0$ (Fig. 6a) the maximum stress is inside the material at a distance of $0.5 \mathrm{l}$ from the contact surface, whereas at $f=0.2$ an additional stress (sub-maximum) emerges at the edge of this surface (Fig. 6b).

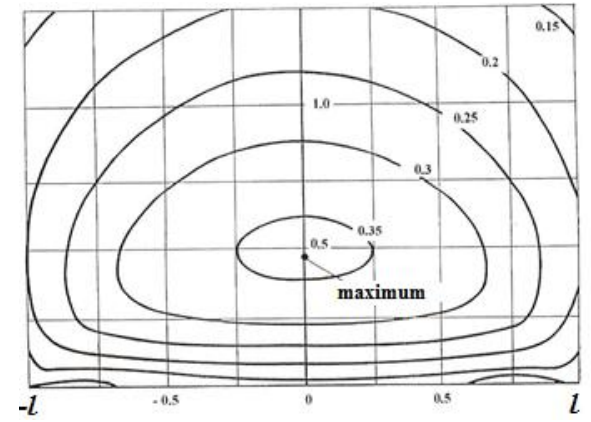

a)

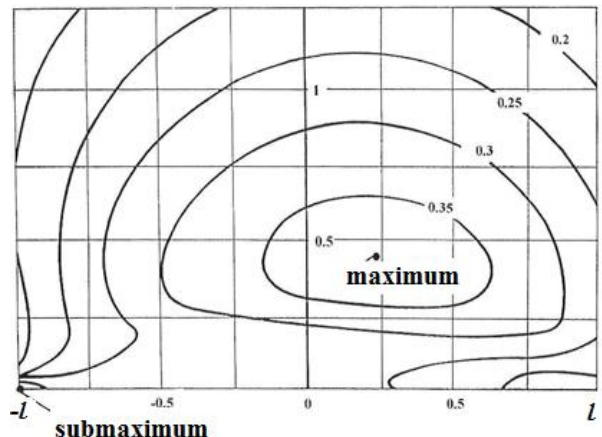

b)

Fig.6. Stress distribution in the material layer of contacting surface at $f=0$ (a) and $f=0.2$ (b);

$l$ - the length of contact semi-axis.

Thus, with increasing friction coefficient the highest stress approaches the surface's outer layer and favours the emergence of cracks and the particle separation. 
Since the irregular character of surface roughness in the given model is described with a normal random field $\mathrm{h}(x, y)$, high peaks of this field can be shown by elliptic paraboloids with the segment volume:

$$
V_{i}=\frac{\pi h_{0}^{2}}{K^{\frac{1}{2}}},
$$

where $h_{0} \quad$ is the height of the paraboloid segment measured from the top;

$K \quad$ is Gauss' bending of the roughness peak:

$$
E\left\{K^{\frac{1}{2}}\right\} \approx \sim E\left\{\left(k_{1} k_{2}\right)^{\frac{1}{2}} \approx \pi^{2} \sigma E\left\{n_{1}(0)\right\} E\left\{n_{2}(0)\right\} \gamma\right.
$$

Thus, parameter $h_{0}$ is the thickness of a particle separated in the wear process (see Fig. 7).

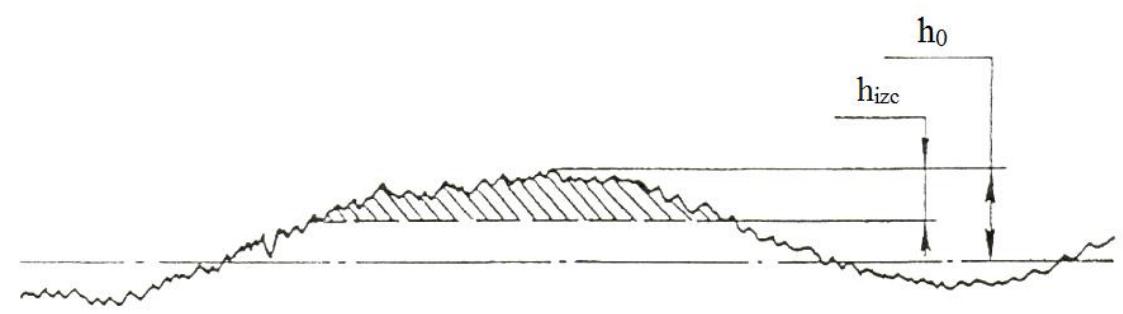

Fig.7. Separation scheme of wear particles at the peak height.

Thus the $h_{0}$ value depends on the situation with the upper layer and other physical and mechanical factors that determine the particle formation during a friction process. Taking into consideration the requirements of the moving contact model, the wearing can proceed according to the following scheme: at the cyclic loading of peak tops (with account taken for imperfection of the material) a crack is being formed in the subsurface layers of the material. Under load the cracks merge, grow, and the particles separate in the form of $h_{0}$ thick scales.

The $h_{0}$ value should be estimated based on the analysis of the upper layer's condition. Then, knowing that in the friction process the stresses are formed at the side end of contact field, it is assumed that separation takes place in the uneven zone of surface roughness that might be slightly above the mid-line, therefore $h_{0} \approx E\left\{h_{a}\right\}$. In turn, the medium peak height $E\left\{h_{a}\right\}$ is calculated as

$$
E\left\{h_{a}\right\}=\left(\gamma+\frac{1}{\gamma}\right) \sigma
$$

As a result, at $\gamma \geq 1$

$$
E\left\{h_{a}\right\} » 2 \sigma .
$$

Considering coherences (18) and (20), the average value of the separated volume of one peak can be determined by the following equation:

$$
E\{V\} \approx \frac{4 \sigma}{\pi E^{2}\left\{\left(n_{1}(0)\right\} c \gamma\right.},
$$


whereas the expected volume of all peaks separated due to friction according to formulas (10) and (20) is:

$$
E\left\{V_{\Sigma}\right\} \approx E\{V\} E\left\{N_{\gamma}\right\} \approx \frac{2 \sigma}{3 \pi \gamma} .
$$

Formula (22) allows the deformed volume to be determined per field unit. At the friction taking place in field $S_{b}$ we will have:

$$
E\left\{V_{\Sigma}\right\} \approx \frac{2}{3} \frac{\sigma S_{b}}{\pi \gamma} .
$$

The friction area is found as

$$
S_{b}=L_{b} l_{b},
$$

where $L_{b} \quad$ is the total length of component friction path;

$l_{b} \quad$ is the width of component friction feet.

In such a case

$$
E\left\{V_{\Sigma}\right\}=\frac{2}{3} \frac{\sigma L_{b} l_{b}}{\pi \gamma} .
$$

Expression (25) allows for determination of the wear product volume at a definite friction path $L_{b}$.

\section{SEQUENCE OF WEAR CALCULATIONS FOR A SLIDING FRICTION PAIR}

Wearing usually proceeds in three stages (Fig.8): the running-in stage, the normal wear stage, and the intensive wear stage; in this last, the friction pair is out of service since the wear will affect its further operation.

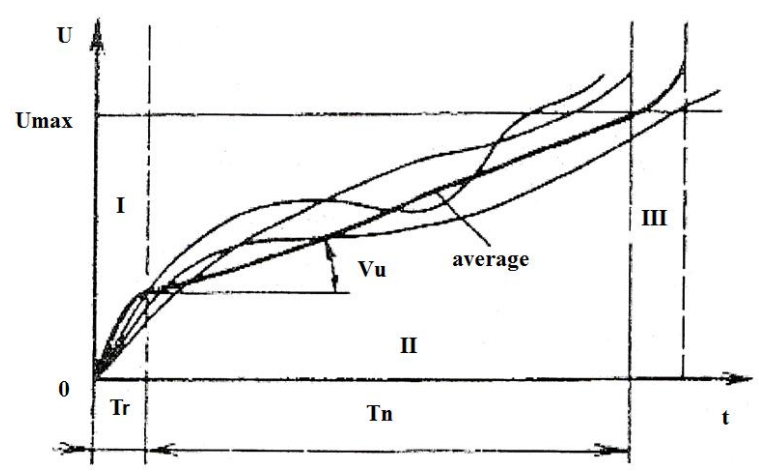

Fig.8. Wear dependence on the fitting operation in stages:

I -running-in stage; II - normal wear stage; III - intensive wear stage

The given calculation model assumes that the running-in and intensive wear stages take only a minor proportion of the whole stability time, thus the maximum wear can be determined as

$$
U_{\max }=U_{r}+U_{n},
$$


where $U_{r}, U_{n}$ is the average wear during the running-in and the normal operation stage, respectively.

In the given case the running-in parameter should be determined experimentally, since this stage involves a large number of highly variable parameters, so these are impossible to estimate and include into calculations. Therefore, the proposed calculation model implies that the average wear $U_{a}$ would be estimated experimentally, with the initial data determined after the running-in stage of a fitting [3].

Most close to understanding the component service life is the linear wear, which can be found by the following coherence:

$$
U_{n}=V_{\Sigma} \frac{N_{c f}}{N_{c}},
$$

where $N_{c f} \quad$ is the actual number of cycles to which the surface peaks are exposed;

$N_{c} \quad$ is the number of cycles leading to destruction of the upper layer's peak.

The real number of cycles can be calculated as

$$
N_{c f}=\frac{L_{b}}{S_{m 2}^{a}},
$$

where $L_{b} \quad$ is the length of friction path;

$S_{m 2}^{a} \quad$ is the mean step of surface roughness towards friction for an active surface (i.e. for the surface that causes wear of another surface).

Thus, using formula (27) and carrying out the necessary alterations, we will obtain the equation for linear wear calculation:

$$
E\left\{U_{n}\right\} \approx E\left\{V_{\Sigma}\right\} \frac{E\left\{N_{c f}\right\}}{E\left\{N_{c}\right\}}=\frac{2}{3 \pi} \sigma \frac{L_{b}}{S_{m 2}^{a}} \frac{5 m !(\pi \sqrt{\pi})^{m}}{\left(3 K^{1 / 2}(e)\right)^{m}}\left(\frac{E}{\sigma_{-1}}\right)^{m}\left(\frac{\sigma}{S_{m 1}}\right)^{m} \frac{1}{\gamma},
$$

where $\gamma$ is a relative surface deformation level.

The deformation level can be determined using basic coherences of the contact theory, according to which [5]

$$
q_{e l}=\frac{k_{q}^{e l} R a}{R S_{m 1} \theta} \cdot F_{1}(\gamma),
$$

where $q_{e l} \quad$ is the pressure on contacting surfaces in elastic contact;

$k_{q}^{e l} \quad$ is a coefficient depending on the roughness

anisotropy coefficient $c$;

$F_{l}(\gamma) \quad$ is the relative surface deformation level's function;

$\theta \quad$ is the constant of the material's elasticity. 
The pressure on contacting surfaces can be found from the following coherence:

$$
q_{e l}=\frac{P}{A_{a}},
$$

where $A_{a}$ is the area of nominal contact.

The elasticity constant for material can be determined as

$$
\theta=\frac{1-\mu^{2}}{\pi E}
$$

Based on E. Students' work [6] according to which for friction surfaces $F_{1}(\gamma) \approx \frac{1}{4 \gamma}, k_{q}^{e l} \approx 0.1$, after alteration of formula (29) we obtain the average linear wear at any point of a friction surface:

$$
E\left\{U_{n}\right\} \approx k_{m} \cdot K_{R} \cdot K_{F-M} \cdot \frac{q}{E} \cdot R a \cdot \frac{L_{b}}{S_{m 2}^{a}},
$$

where $k_{m} \quad$ is a coefficient depending on parameters of the fatigue curve, i.e.:

$$
k_{m}=\frac{25}{3 \pi^{2} N_{o}} m !\left(\frac{\pi}{2}\right)^{(m+1) / 2}\left(\frac{\pi \sqrt{\pi}}{3 K^{1 / 2}(e)}\right)^{m} .
$$

In (33) $K_{R}$ is a set of surface roughness parameters:

$$
K_{R}=\left(\frac{R_{a}}{S_{m 1}}\right)^{m-1}
$$

and $K_{F-M 2 .}-$ a set of physical and mechanical parameters:

$$
K_{F-M}=\frac{E^{m}}{\sigma_{-1}^{m}} .
$$

Formula (33) makes it possible to determine the mean value of linear wear at a point on the friction surface during normal operation at friction coefficient $f \leq 0.1$ and the coefficient of friction surface roughness anisotropy $c \leq 0.1$.

We will link the linear wear with the movement parameters of friction surfaces. At the mutual movement speed of components being $v$, the area $t$, and the full friction path $L_{b}$ we will have:

$$
U_{n}(t)=U_{n} \cdot \frac{v \cdot t}{L_{b}} .
$$

Using formula (33) we finally obtain:

$$
E\left\{U_{n}(t)\right\} \approx k_{m} \cdot K_{R} \cdot K_{F-M} \cdot \frac{q}{E} \cdot \frac{S_{a}}{S_{m 2}^{a}} \cdot v \cdot t
$$


Based on the regularities stated in the previous chapters the following wear calculation conditions can be proposed:

1) The following initial data should be used for further calculations:

- constructive-kinematic characteristic quantities (rated area $A_{a}$ of the subject to wear, load $P$, sliding movement speed $v$, movement time $t$;

- fatigue factor of friction component material (friction coefficient $f$ $(f \leq 0.1)$ and material fatigue destruction parameters $\left(m, \sigma_{-1}, N_{0}\right)$;

- mechanical characteristic quantities of material $(E, \mu)$.

2) The parameters to be stated after the running-in period:

- surface roughness parameters $\left(S_{a}, S_{m 1}, S_{m 2}, S_{m 2}{ }^{a}\right)$;

- initial wear $U_{r}$ and corresponding time $T_{r}$;

- limiting wear $U_{\max }$.

\section{DISCUSSION}

In order to apply the proposed wear calculation model to the engineering tasks we should obtain the necessary experimental data and then make further theoretical calculations. Experimental data are needed only in a fitting's running-in stage, thus it is no use to make any time-consuming and expensive experiments. All the rest parameters that are necessary for the calculations could be received from the technical literature knowing the materials used for the fitting.

\section{CONCLUSIONS}

The main conclusions to be drawn from the results of work are as follows.

1. The valuable assets of our wear calculations are that these are based on combination of the theories from several branches of science, using standardised $3 \mathrm{D}$ roughness parameters, taking into consideration the material's physical and mechanical characteristics as well as definite service conditions of sliding friction pairs.

2. The proposed wear calculation model could be of value for prediction of the exploitation time of sliding friction pairs thus allowing the best technologies to be chosen for mechanical details.

\section{REFERENCES}

1. Kumermanis, M. (2011). Investigations of Irregular Character 3D Surface Roughness Parameters. Riga: Riga Technical University.

2. Rudzitis, J. (1992). Surface Roughness Topography Investigations. In: Internationales Oberflächenkolloquium, 123-128. Chemnitz (Germany): Technische Universität Chemnitz.

3. Konrads, G. (2006). Mašinnu detaļu slīes virsmu dilšana. Riga: Riga Technical University (in Latvian).

4. Hamilton, G. M., \& Goodmen, L. E. (1966). The stress field created by a circular sliding contact. Journal of Applied Mechanics, 125-131.

5. Rudzitis, J., et al. (2005). 3D Roughness Effects on Tribology of Sliding Surfaces. In: Proceedings of the $10^{\text {th }}$ International Conference on Metrology and Properties of Engineering Surfaces, 345-348. Saint Etienne (France): Publication de l'Université de Saint-Etienne.

6. Students E. (1996). Wear Calculation of Sliding Friction Surfaces. Riga: Riga Technical University. 


\title{
DILŠANAS APRĒĶINS SLĪDES BERZES SALĀGOJUMIEM
}

\author{
G. Spriņgís, J. Rudzītis, A. Avišāne, A. Leitāns
}

Kopsavilkums

Mūsdienu ražošanas procesa viens no pamatmērķiem ir produkcijas kvalitātes līmeņa paaugstināšana, tas nozīmē arī dažādu izstrādājumu nepieciešamā kalpošanas laika nodrošināšanu un nodilumizturības palielināšanu. Svarīga loma šī uzdevuma sasniegšanā ir salāgojamo detaļu kalpošanas laika prognozēšanai, kas ir ļoti aktuāls jautājums, jo attīstoties dažādām ražošanas, kā arī mēriekārtu tehnolog̣ijām, kḷūst iespējams arvien precīzāk noteikt nepieciešamos datus, kuri vēlāk tiek izmantoti arī analītiskajos aprēķinos.

Apskatot laika gaitā izstrādātās dilšanas procesa prognozēšanas teorijas, kuras var klasificēt, apkopojot tās noteiktās grupās, ņemot par pamatu līdzīgas teorētiskās pieejas, jāsaka, ka katrai no tām piemît dažādi trūkumi, kuri var ietekmēt rezultātu precizitāti, neievērtējot svarīgus pamatparametrus, kā arī radīt nepieciešamību pēc nelietderīgiem papildus praktiskajiem eksperimentiem, kā rezultātā zūd nepieciešamība pēc teorētiskā aprēķina.

Piedāvātais dilšanas procesa aprēḳinu modelis ir balstîts uz vairāku zinātnes nozaru teoriju pielietošanu, piemērojot šis teorijas 3D virsmas mikrotopogrāfijas aprakstā, ievērtējot materiāla fizikāli-mehāniskos raksturlielumus, pamatojot dilšanas procesā radušos atdalīto materiāla daḷiņu rašanās likumsakarības un ṇemot vērā konkrētus salāgojuma ekspluatācijas apstākḷus.

27.01.2014. 